\title{
PENGARUH KONSENTRASI GARAM DAN LAMA PERENDAMAN TERHADAP MUTU MANISAN CARICA (Carica pubescens)
}

\section{EFFECT OF SALT CONCENTRATION AND SOAKING TIME ON QUALITY OF SWEETENED CARICA (Carica pubescens)}

\author{
Sekar Sari Wulan'), Moh. Su' ${ }^{1}{ }^{1)}$, Enny Sumayati ${ }^{1)}$ \\ ${ }^{1)}$ Teknologi Hasil Pertanian, Fakultas Pertanian, Universitas Widyagama Malang \\ Email: sui_uwg@yahoo.coo.id
}

\begin{abstract}
ABSTRAK
Buah carica merupakan buah yang mengandung vitamin $\mathrm{C}$ dan asam oksalat tinggi. Untuk meningkatkan daya guna buah carica dilakukan diversifikasi pangan dengan membuat manisan. Tujuan penelitian ini adalah mendapatkan konsentrasi garam terbaik dan lama perendaman dalam pembuatan manisan carica. Penelitian ini merupakan penelitian ekperimental 2 faktor yang disusun secara faktorial menggunakan Rancangan Acak Kelompok (RAK). Faktor pertama adalah konsentrasi garam terdiri dari 3 level yaitu 3\%, 6\%, 9\%. Faktor kedua yaitu lama perendaman yang terdiri dari 2 level yaitu 15 menit dan 30 menit. Masing-masing perlakuan diulang tiga kali. Hasil penelitian menunjukkan bahwa kadar vitamin C $24.35 \mathrm{mg} / 100 \mathrm{~g}-31.48 \mathrm{mg} / 100 \mathrm{~g}$, total asam $0.21-0.27 \%$, kalsium oksalat 2550- 3750mg/100g, tekstur 267.167-391.975 g/mm ${ }^{2}$ dan organoleptik pada level suka terdiri atas rasa 3-4.1, warna 3.3-3.9, aroma 3.4-3.6, tekstur 3-3.6, rasa gatal 2.5-3.2. Hasil analisa statistik menunjukkan bahwa interaksi kedua faktor berpengaruh nyata terhadap vitamin $\mathrm{C}$, total asam, kalsium oksalat, rasa, aroma, warna, tekstur, rasa gatal.
\end{abstract}

Kata kunci: carica, garam, manisan, oksalat

\section{ABSTRACT}

Carica fruit is fruit that has high content of vitamine $C$ and oxalic acid. To increase the usefulness of this fruit, food diversification is carried out by making it becomes sweetened carica. The purpose of this research is to get the best salt concentration and soaking time. This research is experimental research with two factors arranged in factorial using Randomized Block Design (RBD). The first factor is the salt concentration consisting of 3 levels, namely 3\%, 6\%, 9\%. The second factor is the soaking time which consists of 2 levels, 15 minutes and 30 minutes. Each treatment was repeated three times. The results showed vitamine $C$ levels is $24.35-31.48 \mathrm{mg} / 100 \mathrm{~g}$, total acids is $0.21-0.27 \%$, calcium oxalate 2550 $3750 \mathrm{mg} / 100 \mathrm{~g}$, texture 267.167-391.975 $\mathrm{g} / \mathrm{mm} 2$ and organoleptics at the like level consisting taste of 3-4.1, color 3.3-3.9, aroma 3.4-3.6, texture 3-3.6, itchy taste 2.5-3.2. The results of statistical analysis showed that the interaction of the two factors significantly affected vitamin $C$, total acid, calcium oxalate, taste, aroma, color, texture, itchy taste.

Keywords: sweetened carica, carica, salt, oxalate 


\section{PENDAHULUAN}

Papaya gunung atau carica (Vanconcellea cundinamarcensis) adalah kerabat pepaya yang menyukai keadaan dataran tinggi basah, $1.500-3.000 \mathrm{~m}$ di atas permukaan laut. Di daerah asalnya wilayah Wonosobo, tanaman ini biasa disebut Carica, dan di Bali tanaman ini disebut Gedang Memedi. Daerah asalnya adalah dataran tinggi Andes, Amerika Selatan.

Buah pepaya dieng berbentuk bulat telur dengan ukuran panjang 6$10 \mathrm{~cm}$ dan diameter $3-4 \mathrm{~cm}$. Buah matang berbentuk telur sungsang dengan ukuran $6-15 \mathrm{~cm} \times 3-8 \mathrm{~cm}$, dagingnya keras, berwarna kuningjingga, rasanya agak asam tetapi harum. Di sekeliling rongganya terdapat banyak sekali biji yang terbungkus oleh sarkotesta yang putih dan berair.

Daging buahnya tidak bisa dikonsumsi langsung harus diolah terlebih dahulu karena mengandung getah yang dapat menimbulkan rasa gatal pada kulit karena adanya kandungan oksalat. Getah ini akan semakin berkurang dengan semakin mendekati kematangan. Getah carica mengandung papain yang bersifat proteolitik (Anonim ${ }^{\mathrm{a}}$, 2017). Menurut Saptonings (2014) garam dapur juga memiliki manfaat sebagai pereduksi bahan makanan mengadung kalsium Oksalat $\left(\mathrm{CaC}_{2} \mathrm{O}_{4}\right)$ yang menimbulkan rasa gatal, sensasi terbakar, dan iritasi pada mulut, tenggorokan, kulit dan saluran pencernaan pada saat di konsumsi.

Perendaman dalam larutan garam $(\mathrm{NaCl})$ banyak dilakukan untuk mengurangi rasa gatal pada talas yang disebabkan oleh kalsium oksalat. (Chotimah dan Fajarini, 2013). Menurut Mutakin (2015), bahwa kadar oksalat talas dengan perlakuan perendaman 120 menit menggunakan air garam 10\% menghasilkan kadar oksalat yang terendah yaitu sebesar 1600 ppm (tereduksi 51,5 \%). Perendaman dengan larutan garam (konsentrasi 1\%) sudah cukup untuk menghilangkan rasa gatal di tenggorokan akibat kandungan asam oksalat pada kulit nanas (Garnadi, 2004). 
Berdasarkan latar belakang di atas, peneliti memandang penting untuk meneliti pengaruh konsentrasi garam dapur dan lama perendaman terhadap mutu manisan carica. Penelitian ini diharapkan menjadi sumbangan teknologi untuk mengatasi permasalahan rasa gatal yang ditimbulkan oleh makanan yang disebabkan oleh kalsium okasalat.

\section{METODE PENELITIAN}

\section{Bahan dan Alat}

Bahan yang digunakan dalam penelitian ini yaitu buah carica, garam dapur, kapur sirih, Kalium Sorbat, air, gula, asam sirat, pewarna sunset yellow, indikator PP., $\mathrm{HCl} 6$ M, Metil Red, $\mathrm{NH}_{4} \mathrm{OH}, \mathrm{CaCl}_{2} 5 \%$, $\mathrm{H}_{2} \mathrm{SO}_{4} 20 \%$ dan $\mathrm{KMnO}_{4} 0.05 \mathrm{M}$.

Alat yang digunakan dalam penelitian ini yaitu timbangan digital, timbangan analitik, baskom, erlenmeyer, gelas beaker, waterbath shaker, hot plate, stirer, sentrifuse , $\mathrm{pH}$ meter, neraca analitik, kompor, pisau, telenan, alat bantu kemas dan bahan kemas plastik.

\section{Rancangan Percobaan}

Penelitian menggunakan dua faktor yang disusun secara faktorial. Faktor pertama adalah konsentrasi larutan garam dapur dengan 3 level yaitu 3\%, 6\% dan 9\%. Faktor kedua adalah lama perendaman dalam larutan garam dengan 2 variasi yaitu 15 menit dan 30 menit. Rancangan yang digunakan adalah Rancangan Acak Kelompok (RAK). Penelitian diulang 3 kali. Data yang diperoleh dianalisis dengan analisis ragam dengnan bantuan (SPSS) versi 14 . Uji lanjut menggunakan uji Beda Nyata Jujur (BNJ).

\section{Pelaksanaan Penelitian}

Buah carica yang telah disortir kemudian dikupas dan dicuci dengan air hingga bersih. Daging buah dipisahkan dengan isi. Daging buah dipotong memanjang dengan ukuran $1 \mathrm{~cm} \times 0.3 \mathrm{~cm}$, selanjutnya direndam dalam bak yang berisi air garam, sesuai perlakuan. Kemudian diangkat dan direndam dalam larutan kapur sirih $1 \%$ selama 15 menit dan dicuci hingga bersih. Selanjutnya diblansing pada suhu $80^{\circ} \mathrm{C}$ selama 10 menit. Pada tahap ini disertakan pula dengan penambahan pewarna methyl 
yellow. Kemudian dicuci dengan air dingin dan ditiriskan.

Larutan gula $70 \%$ dibuat dengan cara menambahkan gula ke dalam air mendidih $100{ }^{0} \mathrm{C}$, kemudian ditambahkan asam sitrat $0.2 \%$ kalium sorbat $1 \mathrm{gr} / \mathrm{lt}$. Selanjutnya daging buah carica dimasukkan ke dalam cup. Sirup gula ditambahkan ke dalam cup yang berisi daging buah carica kemudian ditutup dan direndam selama 12 jam kemudian dianalisa.

\section{Parameter yang Diamati}

Parameter yang diamati pada manisan carica yaitu kadar vitamin $\mathrm{C}$ (AOAC, 1995), total asam (Sudarmadji, dkk., 1984), kadar kalsium oksalat (lwuoha, et al., 1995 dalam Agustin, dkk., 2017), uji tekstur (Tahalatu, 2011), organoleptik meliputi rasa, warna, aroma, tekstur dan rasa gatal (Setyaningsih, 2010). Pengamatan hanya dilakukan pada lama perendaman 30 menit.

\section{HASIL DAN PEMBAHASAN Vitamin C}

Hasil anova menunjukkan interaksi antara konsentrasi garam dan lama perendaman berpengaruh nyata terhadap vitamin $\mathrm{C} \operatorname{sig} \alpha<$ 0.05. Kadar vitamin $\mathrm{C}$ manisan carica dapat dilihat pada Gambar 1 .

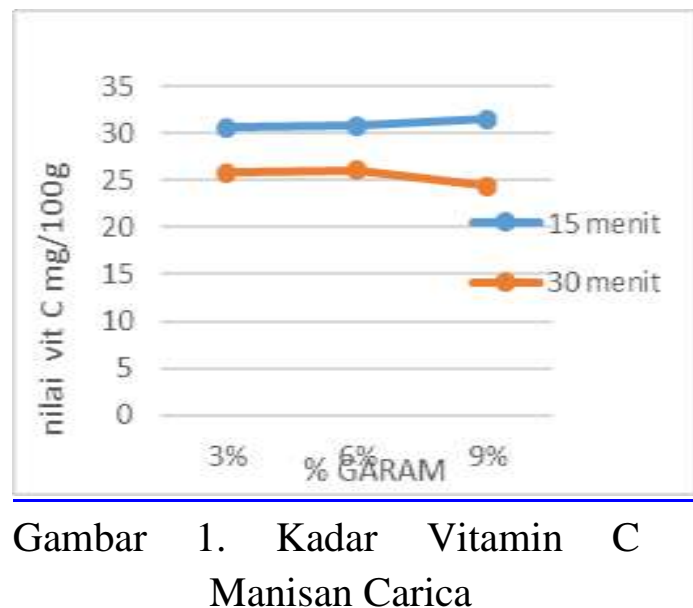

Gambar 1 menunjukkan bahwa perendaman 15 menit dengan konsentrasi garam 3\%, 6\%, 9\% kadar vitamin $\mathrm{C}$ tidak menunjukkan perbedaan yang signifikan. Perendaman 30 menit menunjukkan kadar vitamin $\mathrm{C}$ cenderung menurun dengan meningkatnya konsentrasi garam. Hal ini karena perendaman menyebabkan air yang keluar dari dalam bahan semakin lama semakin banyak sehingga semakin besar kehilangan vitamin C. Hal ini sesuai sifat alami dari vitamin $\mathrm{C}$ yang mudah larut dalam air, sehingga semakin lama perendaman buah maka kandungan vitamin $\mathrm{C}$ yang 
terukur semakin berkurang (Kartika, 2015).

Vitamin C merupakan kristal putih yang mudah larut dalam air. Dalam keadaan kering, vitamin $\mathrm{C}$ cukup stabil tetapi dalam keadaan larut, vitamin $\mathrm{C}$ mudah rusak karena bersentuhan dengan udara (oksidasi) terutama bila terkena panas (Almatsier, 2005).

\section{Total Asam}

Hasil anova menunjukkan interaksi antara konsentrasi garam dan lama perendaman menunjukkan pengaruh nyata terhadap total asam sig $\alpha<0.05$. Total asam manisan carica dapat dilihat pada Gambar 2 .

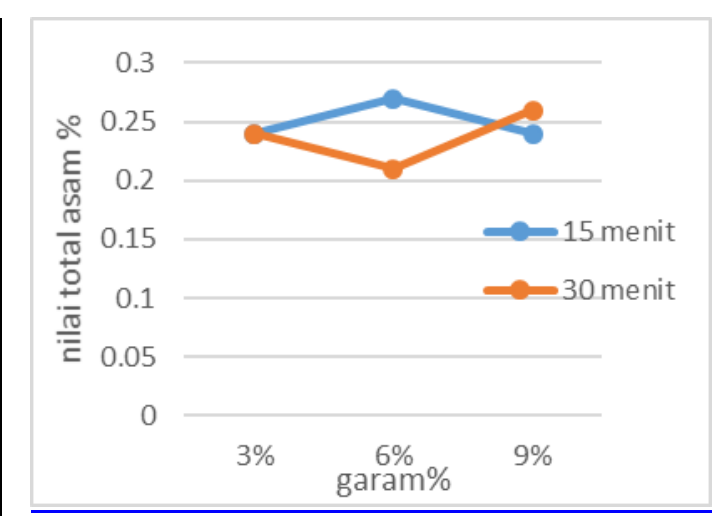

Gambar 2. Total Asam Manisan Carica

Gambar 2 menunjukkan bahwa pada lama perendaman 15 menit konsentrasi garam $6 \%$ total asam naik kemudian turun seiring penambahan garam 9\%. Sebaliknya perendaman 30 menit, konsentrasi garam $6 \%$ total asam turun kemudian naik pada konsentrasi garam 9\%.

Penurunan total asam disebabkan oleh sifat asam secara umum yang mudah rusak. Diduga penurunan total asam pada manisan carica disebabkan perendaman dalam air yang menyebabkan penurunan asam organik seperti asam askorbat. Selain itu penambahan garam juga dapat menurunkan asam oksalat pada manisan carica. Kerusakan asam dapat dipercepat dengan adanya panas, sinar, alkali, enzim, oksidator, serta katalis tembaga dan besi (Winarno 2008 dalam Rahmawati (2015).

\section{Kalsium oksalat}

Hasil anova menunjukkan konsentrasi larutan garam menunjukkan pengaruh nyata terhadap kalsium aksalat sig $\alpha<$ 0.05. Reduksi kalsium oksalat $\left(\mathrm{CaC}_{2} \mathrm{O}_{2}\right)$ pada manisan carica menunjukkan bahwa perlakuan garam konsentrasi 3\%, 6\%, 9\% dapat menurunkan kandungan kalsium oksalat dalam manisan carica dengan nilai 2550 - 3750mg/100g. Pada 
buah carica segar sebelum perlakuan dihasilkan kadar kalsium oksalat sebesar 7500mg/100g. Kadar kalsium oksalat dalam manisa carica dapat dilihat pada Tabel 1.

Tabel 1. Rerata Kadar Kalsium Oksalat

\begin{tabular}{l|c|c}
\hline Perlakuan & $\begin{array}{l}\text { Rerata } \\
\text { kalsium } \\
\text { oksalat } \\
\mathrm{mg} / 100 \mathrm{~g}\end{array}$ & $\begin{array}{c}\text { Penurunan } \\
(\%)\end{array}$ \\
\hline Garam 9\% & $2550 \mathrm{a}$ & 66 \\
\hline Garam 6\% & $2850 \mathrm{a}$ & 63 \\
\hline Garam 3\% & $3750 \mathrm{~b}$ & 50 \\
\hline
\end{tabular}

Keterangan: Angka yang didampingi notasi yang berbeda menunjukkan hasil yang berbeda nyata.

Tabel 1 menunjukkan reduksi kalsium oksalat meningkat seiring penambahan konsentrasi garam. Reduksi oksalat tertinggi pada perlakuan konsentrasi garam 9\% pada lama perendaman 30 menit yaitu dengan kandungan kalsium oksalat $2550 \mathrm{mg} / 100 \mathrm{~g}$ atau penurunan sebesar $66 \%$. Penurunan terendah pada perlakuan konsentrasi garam 3\% dan lama perendaman 30 menit dengan kandungan kalsium oksalat $3.735 \mathrm{mg} / 100 \mathrm{~g}$ atau penurunan sebesar $50 \%$.
Hal ini sesuai dengan penelitian Chotimah dan Fajarini (2013), semakin besar konsentrasi garam yang digunakan akan semakin besar tingkat penurunan kandungan kalsium oksalat. Hal ini karena garam yang ditambahkan akan terionisasi di dalam air menjadi ion $\mathrm{Na}^{+}$dan $\mathrm{Cl}^{-}$. Ion $\mathrm{Na}^{+}$akan berikatan dengan kalsium oksalat membentuk natrium oksalat dan endapan kalsium diklorida yang larut dalam air dan lama perendaman akan menurunkan kadar oksalat ini sesuai dengan penelitian Oke, et al., (2012) dalam Agustin dkk (2017).

Batas aman konsumsi kalsium oksalat bagi orang dewasa adalah $0.60-1.25 \mathrm{~g} / \mathrm{hari}$ selama 6 minggu berturut-turut (Khan, et al., 2007: Knudesen, et al., 2008) dalam (Agustin, dkk., 2017). Oleh karena itu perlu dilakukan reduksi oksalat pada manisan carica agar dapat dikonsumsi tanpa menimbulkan rasa gatal dan juga aman bagi tubuh tanpa memberikan efek negatif terhadap kesehatan.

\section{Tekstur}

Hasil anova menunjukkan bahwa konsentrasi garam 
berpengaruh nyata terhadap tekstur manisan carica nilai sig $\alpha<0.05$. Nilai tekstur manisan carica dapat dilihat pada Tabel 2 .

Tabel 2. Nilai Rerata pada Uji

\begin{tabular}{l|l}
\multicolumn{2}{c}{ Tekstur } \\
$\begin{array}{l}\text { Konsentrasi } \\
\text { garam (\%) }\end{array}$ & Tekstur $\left(\mathrm{g} / \mathrm{mm}^{2}\right)$ \\
\hline Garam 3\% & $229.41 \mathrm{a}$ \\
\hline Garam 6\% & $306.73 \mathrm{ab}$ \\
\hline Garam 9\% & $368.93 \mathrm{~b}$ \\
\hline Keterangan: Angka yang didampingi \\
notasi yang berbeda \\
menunjukkan hasil \\
yang berbeda nyata.
\end{tabular}

Tabel 2 menunjukkan bahwa tingkat kekerasan manisan carica meningkat seiring dengan peningkatan konsentrasi garam. Peningkatan konsentrasi garam akan meningkatkan tekanan osmosis sehingga kandungan air di dalam manisan carica semakin berkurang. Hasil penelitian Vega-Galvez, et al., (2008) dalam Rahmawati (2015) menunjukkan bahwa perendaman paprika merah dalam larutan natrium klorida sebelum proses pengeringan menyebabkan penebalan dinding sel. Dengan terbentuknya kalisium pektat dan meningkatnya aktivitas enzim pectin methylesterase. Hal tersebut menyebabkan tekstur produk menjadi lebih kompak dan semakin keras seiring dengan berkurangnya kadar air.

\section{Organoleptik}

Rasa

$\begin{array}{cc}\text { Analisa } & \text { ragam non } \\ \text { parametric menggunakan tes }\end{array}$
Kruskal Wallis menunjukkan adanya interaksi antara konsentrasi garam dan lama perendaman terhadap rasa manisan carica $\alpha<0.05$. Pada perendaman 30 menit, kesukaan panelis terhadap manisan menurun. Hal ini diduga karena terlalu lama perendaman sehingga kandungan garam yang diserap oleh buah carica semakin banyak. Sedangkan perendaman 15 menit kesukaan panelis terhadap rasa manisan carica cenderung meningkat. Menurut pendapat panelis, adanya keseimbangan rasa antara asam, manis dan asin.

\section{Warna}

Analisa ragam non parametric menggunakan tes Kruskal Wallis menunjukkan adanya interaksi antara konsentrasi garam dan lama perendaman terhadap 
warna manisan carica $\alpha<0.05$. Perendaman 15 menit dan 30 menit kesukaan terhadap warna turun pada konsentrasi garam 6\% kemudian naik pada konsentrasi garam $9 \%$. Hal ini diduga karena garam dapur yang masuk ke jaringan buah dapat menghambat proses pencoklatan non enzimatis. Menurut Faust and Klien (1973) dalam Faiqoh (2014) bahwa garam dapur dapat mencegah terjadinya pencoklatan non enzimatis, karena ion $\mathrm{Na}^{2+}$ akan berikatan dengan asam-asam amino sehingga menghambat reaksi antara amino dengan gula reduksi yang menyebabkan pencoklatan.

\section{Aroma}

Hasil analisa ragam non parametric menggunakan tes Kruskal Wallis test menunjukkan adanya interaksi antara konsentrasi garam dan lama perendaman terhadap aroma manisan carica $\alpha<$ 0.05 . Tingkat kesukaan aroma yang tertinggi terdapat pada perlakuan garam 3\% dan lama perendaman 15 menit dengan skor 3.6 serta perlakuan garam 9\% dan lama perendaman 15 menit. Sedangkan yang paling rendah terdapat pada perlakuan garam 3\% dan lama perendaman 30 menit. Hal ini diduga perendaman menyebabkan senyawa aroma ikut larut sehingga aroma berkurang.

\section{Tekstur}

Hasil analisa ragam non parametric menggunakan tes Kruskal Wallis menunjukkan adanya interaksi antara konsentrasi garam dan lama perendaman terhadap testur manisan carica $\alpha<0.05$. Pada perendaman 15 menit dan 30 menit kesukaan panelis terhadap tekstur meningkat pada konsentrasi garam 6\% tetapi tingkat kesukaan terhadap tekstur cenderung menurun pada konsentrasi garam 9\%. Kesukaan panelis terhadap tekstur tertinggi terdapat pada level $6 \%$ dan lama perendaman 15 menit ini menunjukkan bahwa panelis menyukai tekstur yang tidak terlalu keras, sebab semakin tinggi konsentrasi garam dan lama perendaman ini disebabkan peristiwa osmosis di mana kandungan air di dalam manisan carica semakin berkurang.

Hasil penelitian Vega-Galvez, et al., (2008) dalam Rahmawati 
(2015) mengenai efek perendaman paprika merah dalam larutan natrium klorida sebelum proses pengeringan menyebabkan penebalan dinding sel karena terbentuknya kalisium pektat dan meningkatnya aktivitas enzim pectin methylesterase. Hal tersebut menyebabkan tekstur produk menjadi lebih kompak dan semakin keras seiring dengan berkurangnya kadar air.

\section{Rasa Gatal}

Hasil analisa ragam non parametric menggunakan tes Kruskal Wallis menunjukkan adanya interaksi antara konsentrasi garam dan lama perendaman terhadap rasa gatal manisan carica $\alpha<0.05$. Dengan meningkatnya konsentrasi garam dan lama perendaman meningkatkan kesukaan panelis. Ini menunjukkan rasa gatal yang timbul pada manisan carica berkurang sebab semakin tinggi garam maka semakin banyak kalsium oksalat yang akan larut dalam air di mana garam $(\mathrm{NaCl})$ akan terionisasi menjadi ion $\mathrm{Na}^{+}$dan $\mathrm{Cl}^{-}$yang akan berikatan dengan kalsium oksalat membentuk natrium oksalat $\left(\mathrm{NaC}_{2} \mathrm{O}_{4}\right)$ yang larut dalam air (Chotimah dan Fajarini, 2013).

\section{KESIMPULAN DAN SARAN}

\section{Kesimpulan}

Hasil penelitian menunjukkan bahwa Kedua faktor perlakuan memberikan interaksi nyata terhadap parameter vitamin $\mathrm{C}$, total asam, kalsium oksalat, rasa, aroma, warna, tekstur, gatal.

Hasil dari penelitian untuk uji vitamin C $24.35-31.48 \mathrm{mg} / 100 \mathrm{~g}$, total asam $0.21-0.27 \%$, kalsium oksalat 2550-3750mg/100g, tekstur 267.167$391.975 \mathrm{~g} / \mathrm{mm}^{2}$, rasa skor 3.0-4.1, warna skor 3.3-3.9, aroma skor 3.43.6, tekstur skor 3.0-3.6, gatal skor 2.4-3.2.

\section{Saran}

Perlu dilakukan penelitian lebih lanjut mengenai daya simpan manisan carica tanpa menggunakan pengawet kimia.

\section{DAFTAR PUSTAKA}

Agustin, dkk. 2017. Penurunan Oksalat pada Proses Perendaman Umbi Kimpul (Xanthosoma sagittifolium) di Berbagai Konsentasi Asam Asetat. Jurnal Teknologi Pertanian. Vol 18 (3). 
Anonim ${ }^{a}$, 2017. Tumbuhan Carica Gunung.

http://caricaku.com/caricadieng-wonosobo-pepayagunung-khas-wonosobo. Diakses pada hari Minggu, 10 April 2017.

AOAC. 1995. Association of Official Analytical Chemistri, Oficial Method of Analysis. $18^{\text {th }}$ edition. Benjamin Frangklin. Washington D. C.

Almatsier, S. 2005. Prinsip Dasar Ilmu Gizi. Bandung: Alfabeta.

Chotimah dan Fajarini, 2013. Reduksi Kalsium Oxalat dengan Perebusan Menggunakan Larutan $\mathrm{NaCl}$ dan Penepungan Meningkatkan Kualitas Sente (Alocasia macrorrhiza) sebagai Bahan Pangan. Jurnal teknologi kimia dan industri. JKTI. Vol 2 (2).

Faiqoh, E. 2014. Pengaruh Konsentrasi dan Lama Perendaman dalam $\mathrm{NaCl}_{2}$ (Kalsium Klorida) terhadap Kualitas dan Kuantitas Buah Naga Super Merah. Jurusan Biologi Fakultas Sains dan Teknologi. UIN.

Garnadi. 2004. Dokumentasi Kliping IPTEK. Bandung: UPT Balai Informasi Teknologi LIPI. Vol 2 (9).

Kartika. 2015. Studi Pembuatan Osmodehidrat Buah Nanas (Ananas cosmosus L. Merr): Kajian Konsentrasi Gula dalam Larutan Osmosis dan Lama Perendaman. Jurnal
Teknologi Hasil Pertanian. Vol 3 (4).

Rahmawati. 2015. Pengaruh Lama Pengeringan terhadap Mutu Manisan Kering Buah Carica (Carica candimarcencis). Jurnal Teknologi Pangan. Vol 4 (2).

Saptonings. 2014. Menghilangkan Zat Antinutrisi pada Talas. http://bbpp-lembang.info.

diakses pada 6 Desember 2017

Setyaningsih, D., A. Apriantono dan M. Puspitasari. 2010. Analisis Sensori untuk Industri Pangan dan Agro. 